\title{
Implementasi Pendidikan Karakter Sopan Santun Siswa Melalui Media Cantik di SD Negeri 11 Mataram
}

\author{
Baiq Nurul Hidayani \\ SD Negeri 11 Mataram, Kota Mataram - Provinsi NTB \\ Corresponding Author. Email: bqnurulh@gmail.com
}

\begin{abstract}
This study aims to describe the implementation of the character education of students' courtesy through beautiful media at SD Negeri 11 Mataram. This research method using descriptive method. Data collection techniques in this study using observation and documentation. The data analysis technique used thematic analysis. The results of this study indicate that the use of beautiful media in improving the character of courtesy of students at SD Negeri 11 Mataram shows the results and can provide concrete experiences for students in being polite in everyday life, especially at school.
\end{abstract}

Article History

Received: 11-02-2021

Revised: 13-03-2021

Published: 04-04-2021

\section{Key Words:}

Character Education, Politeness, Beautiful Media.

\section{Sejarah Artikel}

Diterima: 11-02-2021

Direvisi: 13-03-2021

Diterbitkan: 04-04-2021

\section{Kata Kunci:}

Pendidikan Karakter, Sopan Santun, Media Cantik.

How to Cite: Hidayani, B. (2021). Implementasi Pendidikan Karakter Sopan Santun Siswa Melalui Media Cantik di SD Negeri 11 Mataram. Jurnal Paedagogy, 8(2). doi:https://doi.org/10.33394/jp.v8i2.3560

https://doi.org/10.33394/jp.v8i2.3560

This is an open-access article under the CC-BY-SA License.

\section{Pendahuluan}

Pendidikan di Indonesia, saat ini sedang berusaha mengkaji kembali perlunya pendidikan pendidikan karakter dengan penerapan kurikulum 2013. Pengembangan pendidikan karakter saat ini perlu untuk dilakukan, karena kualitas peserta didik dalam kepribadian dan karakter merupakan hal penting yang harus dipikirkan dengan baik-baik. Banyaknya permasalahan yang berkaitan dengan karakter di lingkungan sekolah seharusnya menjadi pemikiran bersama. Krisis karakter yang terjadi di kalangan siswa ditandai dengan adanya berbagai pelanggaran (Nitte \& Bulu, 2020; Sari, 2018). Menurut Zubaedi dalam Ramdhani (2014) menyatakan bahwa demoralisasi ini terjadi karena proses pembelajaran cenderung mengajarkan pendidikan moral dan budi pekerti sebatas tekstual semata dan kurang mempersiapkan pembelajar untuk menyikapi kehidupan yang kontradiktif tersebut. Oleh Karena itu, penguatan pendidikan moral (moral education) atau pendidikan karakter (character education) dalam konteks sekarang sangat relevan untuk mengatasi krisis moral yang sedang melanda di negara kita (Akhwan, 2014).

Idealnya pendidikan yang dibangun bangsa ini haruslah merujuk dengan tujuan yang telah di tetapkan dalam UU Sisdiknas, pendidikan karakter (watak) adalah amanat UndangUndang Nomor 23 Tahun 2003 tentang Sistem Pendidikan Nasional pasal 3 menegaskan bahwa "Pendidikan nasional berfungsi mengembangkan kemampuan dan membentuk watak serta peradaban bangsa yang bermartabat dalam rangka mencerdaskan kehidupan bangsa, 
bertujuan untuk berkembangnya potensi peserta didik agar menjadi manusia yang beriman dan bertaqwa kepada Tuhan Yang Maha Esa, berakhlak mulia, sehat, berilmu, cakap, kreatif, mandiri dan menjadi warga Negara yang demokratis serta bertanggungjawab". Pendidikan karakter bertujuan untuk menanamkan sikap positif pada anak sejak usia dini melalui pembiasaan sehingga tumbuh menjadi pribadi yang berperilaku baik (Nuraeni, 2020; Irawan, 2020; Faqih, 2018)

Hal tersebut menunjukkan bahwa pendidikan disekolah harus dapat membentuk karakter yang lebih baik. Mengacu dengan tujuan pendidikan nasional yang telah di jabarkan sebelumnya, seharusnya nilai-nilai yang dikembangkan dalam pendidikan menjadi dasar sebagai kurikulum sekolah yang bertujuan mengembangkan secara berkesinambungan dan sistematis karakter siswa. Implementasi pendidikan hendaknya berbasiskan kepada seperangkat nilai sebagai panduan antara kesinambungan ranah kognitif, afektif dan psikomotor (Noor, 2012).

Fenomena terkait rendahnya karakter siswa disekolah, khususnya perilaku sopan siswa terhadap guru terjadi di SD Negeri 11 Mataram. Bentuk perilaku rendahnya sikap sopan siswa ditunjukkan dari hasil Observasi yang dilakukan terhadap siswa kelas V pada tanggal 20 September 2019, terlihat bahwa masih terdapat siswa yang sering berkata kasar atau kotor, selain itu siswa juga berani membantah perintah guru. Komunikasi antara siswa dengan guru juga menunjukkan rendahnya sikap sopan santun, misalnya siswa tidak menggunakan bahasa yang baik saat berbicara dengan guru nya. Interaksi guru dan siswa juga menunjukkan rendahnya sikap sopan santun, dari hasil Observasi dijelaskan ada siswa yang terlambat masuk kelas tetapi tidak memberikan salam atau ungkapan permisi kepada guru yang telah berada lebih dulu di dalam kelas, selain itu jika ada guru yang menegur, siswa berlaku cuek pada gurunya. Kemudian interaksi di dalam kelas antara guru dan siswa juga menunjukkan sikap kurangnya sopan santun, yaitu jika guru sedang menjelaskan di depan siswa tidak mendengarkan dengan baik, ramai atau ngobrol dengan temannya.

Hal yang sama juga diperoleh dari observasi terhadap siswa kelas IV, dari hasil observasi masih ditemukan siswa yang berperilaku tidak sopan terhadap guru adalah siswa laki-laki. Siswa berlaku tidak sopan terhadap guru pada saat ditegur oleh guru yaitu dengan berbicara kotor atau menggerutu. Dari cara berpakaian, banyak siswa yang kurang sopan yaitu biasanya siswa tidak memasukkan baju seragam. Selain itu saat berinteraksi dengan guru, banyak siswa yang acuh atau tidak menegur guru padahal siswa tersebut jalan di depan guru.

Permasalahan tersebut haruslah segera ditangani dengan berbagai upaya dan peran dari guru di lingkungan sekolah. Guru bertanggung jawab bukan saja pada aspek kognitif, tetapi juga aspek perkembangan sosial, maka hal ini menjadi perhatian dengan mencarikan solusi pemecahannya melalui layanan bimbingan.

Menurut Noor (2012) tentang peranan guru disekolah, keluarga, masyarakat dipandang dari segi diri pribadinya (self-oriented), seorang guru harus berperan sebagai: (1). Pekerja social, yaitu seseorang yang harus memberikan pelayanan kepada masyarakat, (2). Pelajar dan Ilmuan, yaitu seseorang yanag harus senantiasa belajar secara terus menerus untuk mengembangan penguasaan keilmuannya, (3). Orang tua, artiya guru adalah wakil orang tua peserta didik bagi setiap peserta didik di sekolah, (4). Model Keteladanan, artinya guru adalah model perilaku yang harus di contoh oleh peserta didik, (5). Pemberi rasa aman dan kasih sayang bagi setiap peserta didik, peserta didik diharapkan akan merasa aman berada dalam didikan gurunya. 
Adapun tujuan penelitian best practices ini adalah untuk mendeskripsikan implementasi pendidikan karakter sopan santun siswa melalui media audio visual cantik (Contohkan Amati Laksanakan) di SD Negeri 11 Mataram.

\section{Metode Penelitian}

Metode penelitian ini menggunakan metode deskriptif dengan subyek penelitian yakni siswa SD Negeri 11 Mataram. Teknik pengumpulan data dalam penelitian ini menggunakan observasi (pengamatan) dan dokumentasi. Pengamatan dilakukan secara bebas dan terstruktur. Alat yang bisa digunakan dalam pengamatan adalah lembar pengamatan, ceklist, catatan kejadian dan lain-lain. Beberapa informasi yang diperoleh dari hasil observasi adalah ruang (tempat), pelaku, kegiatan, objek, perbuatan, kejadian atau peristiwa, waktu, perasan. Alasan peneliti melakukan observasi adalah untuk menyajikan gambaran realistik perilaku atau kejadian, untuk menjawab pertanyaan, untuk membantu mengerti perilaku manusia, dan untuk evaluasi yaitu melakukan pengukuran terhadap aspek tertentu melakukan umpan balik terhadap pengukuran tersebut. Kuesioner (angket) merupakan teknik pengumpulan data yang dilakukan dengan cara memberikan seperangkat pertanyaan atau pernyataan tertulis kepada responden untuk dijawabnya, dimana peneliti tidak langsung bertanya jawab dengan responden. Dokumen merupakan sumber data yang digunakan untuk melengkapi penelitian, baik berupa sumber tertulis, film, gambar (foto), dan karya-karya monumental, yang semua itu menberikan informasi bagi proses penelitian.

Proses analisis data penelitian ini dimulai dengan menelah seluruh data yang tersedia dari berbagai sumber, yaitu pengamatan yang sudah ditulis dalam catatan lapangan, dokumen pribadi, dokumen resmi, gambar foto, dan sebagainya. Setelah semua data dibaca, dipelajari, dan ditelah maka langkah berikutnya adalah mengadakan reduksi data yang dilakukan dengan membuat abstraksi. Abstraksi merupakan usaha membuat rangkuman inti, proses dan pernyataan-pernyataan yang perlu dijaga sehingga tetap berada di dalamnya. Langkah selanjutnya adalah menyusunya dalam satuan-satuan. Satuan atau unit adalah satuan suatu latar sosial. Satuan-satuan itu kemudian dikategorisasikan pada langkah berikutnya. Kategori-kategori itu dilakukan sambil membuat koding. Tahap akhir dari analisis data ialah mengadakan pemeriksaan keabsahan data. Setelah selesai tahap ini, mulailah kini tahap penafsiran data dalam mengolah hasil sementara menjadi teori substantif dengan menggunakan beberapa metode tertentu (Moleong, 2017).

\section{Hasil Penelitian dan Pembahasan}

Langkah-langkah yang ditempuh dalam implementasi karakter sopan santun siswa di SD Negeri 11 Mataram dilakukan melalui siklus SPMI yang meliputi penetapan standar mutu, pemetaan mutu, penyusunan rencana pelaksanaan pemenuhan mutu, implementasi pemenuhan mutu dan evaluasi/audit mutu.

\section{Penetapan Standar Mutu}

Standar mutu sekolah ditetapkan melalui rapat penetapan standar mutu yang di hadiri oleh kepala sekolah, tim pengembang mutu dan komite sekolah. Standar mutu yang ditetapkan sekolah berdasarkan standar nasional pendidikan. Adapun standar mutu yang ditetapkan terdapat pada tabel berikut ini.

Tabel 1. Standar Mutu

\begin{tabular}{|l|l|l|}
\hline No & Standar Mutu & \multicolumn{1}{c|}{ Indikator } \\
\hline 1 & $\begin{array}{l}\text { Kompetensi } \\
\text { Lulusan }\end{array}$ & $\begin{array}{l}\text { Lulusan memiliki kompetensi pada dimensi sikap } \\
\text { Lulusan memiliki kompetensi pada dimensi pengetahuan }\end{array}$ \\
\hline
\end{tabular}




\begin{tabular}{|c|c|c|}
\hline & & Lulusan memiliki kompetensi pada dimensi keterampilan \\
\hline 2 & Isi & $\begin{array}{l}\text { Perangkat pembelajaran sesuai rumusan kompetensi lulusan } \\
\text { Kurikulum Tingkat Satuan Pendidikan dikembangkan sesuai } \\
\text { prosedur } \\
\text { Sekolah melaksanakan kurikulum sesuai ketentuan }\end{array}$ \\
\hline 3 & Proses & $\begin{array}{l}\text { Sekolah merencanakan proses pembelajaran sesuai ketentuan } \\
\text { Proses pembelajaran dilaksanakan dengan tepat } \\
\text { Pengawasan dan penilaian otentik dilakukan dalam proses } \\
\text { pembelajaran }\end{array}$ \\
\hline 4 & $\begin{array}{l}\text { Penilaian } \\
\text { Pendidikan }\end{array}$ & $\begin{array}{l}\text { Aspek penilaian sesuai ranah kompetensi } \\
\text { Teknik penilaian obyektif dan akuntabel } \\
\text { Penilaian pendidikan ditindaklanjuti } \\
\text { Instrumen penilaian menyesuaikan aspek } \\
\text { Penilaian dilakukan mengikuti prosedur }\end{array}$ \\
\hline 5 & $\begin{array}{l}\text { Pendidik Dan } \\
\text { Tenaga } \\
\text { Kependidikan }\end{array}$ & $\begin{array}{l}\text { Ketersediaan dan kompetensi guru sesuai ketentuan } \\
\text { Ketersediaan dan kompetensi kepala sekolah sesuai ketentuan } \\
\text { Ketersediaan dan kompetensi tenaga administrasi sesuai } \\
\text { ketentuan } \\
\text { Ketersediaan dan kompetensi laboran sesuai ketentuan } \\
\text { Ketersediaan dan kompetensi pustakawan sesuai ketentuan }\end{array}$ \\
\hline 6 & $\begin{array}{l}\text { Sarana dan } \\
\text { Prasarana } \\
\text { Pendidikan }\end{array}$ & $\begin{array}{l}\text { Kapasitas daya tampung sekolah memadai } \\
\text { Sekolah memiliki sarana dan prasarana pembelajaran yang } \\
\text { lengkap dan layak } \\
\text { Sekolah memiliki sarana dan prasarana pendukung yang lengkap } \\
\text { dan layak }\end{array}$ \\
\hline 7 & $\begin{array}{l}\text { Pengelolaan } \\
\text { Pendidikan }\end{array}$ & $\begin{array}{l}\text { Sekolah melakukan perencanaan pengelolaan } \\
\text { Program pengelolaan dilaksanakan sesuai ketentuan } \\
\text { Kepala sekolah berkinerja baik dalam melaksanakan tugas } \\
\text { kepemimpinan } \\
\text { Sekolah mengelola sistem informasi manajemen }\end{array}$ \\
\hline 8 & Pembiayaan & $\begin{array}{l}\text { Sekolah memberikan layanan subsidi silang } \\
\text { Beban operasional sekolah sesuai ketentuan } \\
\text { Sekolah melakukan pengelolaan dana dengan baik }\end{array}$ \\
\hline
\end{tabular}

\section{Pemetaan Mutu}

Tahap yang dilakukan setelah penetapan standar mutu adalah pemetaan mutu yang diawali dengan rapat tim pengembang untuk memetakan mutu pendidikan di SDNegeri 11 Mataram dengan menganalisis rapor mutu tahun 2018. Berdasarkan hasil analisis rapor mutu terlihat bagian yang lemah terdapat pada standar sarana dan prasarana. Adapun hasil pemetaan mutu diperoleh dokumen berupa tabel analisis data mutu SD Negeri 11 Mataram, jaring-jaring akar permasalahan dan tabel analisis akar masalah yang berisi rekomendasi perbaikan terhadap akar masalah tersebut.

\section{Tabel 2. Analisis Data Mutu SD Negeri 11 Mataram}

\begin{tabular}{|c|c|c|c|}
\hline No & Indikator & Kekuatan & Kelemahan \\
\hline 1.1 & $\begin{array}{l}\text { Lulusan } \\
\text { memiliki } \\
\text { kompetensi pada }\end{array}$ & $\begin{array}{l}\text { Memiliki perilaku yang } \\
\text { mencer minkan sikap beriman } \\
\text { dan bert akwa kepada Tuhan }\end{array}$ & $\begin{array}{l}\text { Memiliki perilaku yang } \\
\text { men cerminkan sikap } \\
\text { disiplin }(6.91), \text { Memiliki }\end{array}$ \\
\hline
\end{tabular}




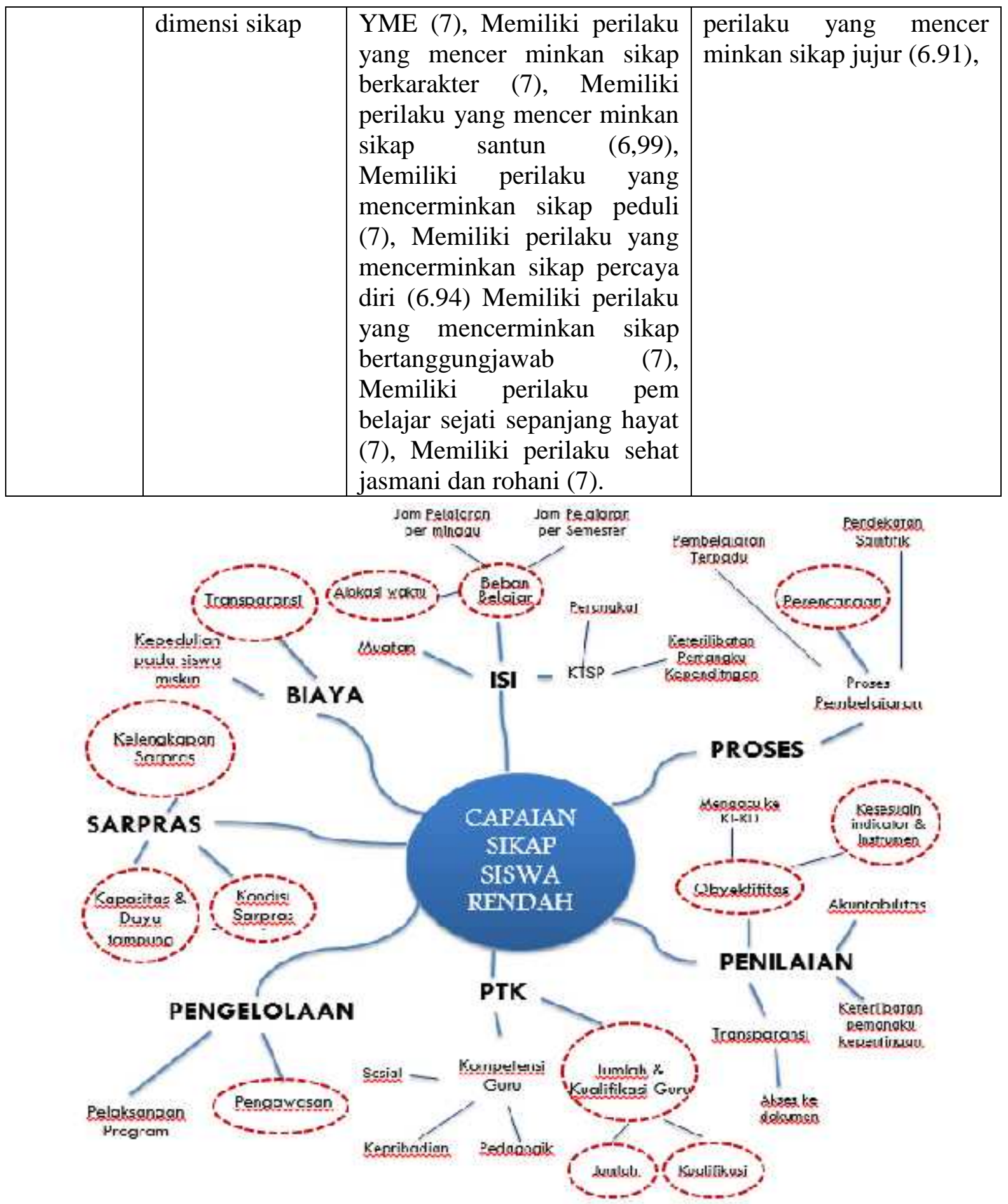

Gambar 1. Jaring-Jaring Akar Permasalahan

Tabel 3. Analisis Akar Masalah

Masalah : Capaian Sikap Siswa Rendah 
1. Kepala sekolah, guru, tenaga kependidikan belum bisa dijadikan teladan oleh siswa.

2. Kompetensi sikap ini belum diintegrasikan dengan baik dalam kegiatan pembelajaran di sekolah.

3. Guru merasa terbebani dalam memberikan penilaian sikap karena instrumen dan prosedur yang rumit dan kurang dipahami.

4. Kurangnya komunikasi antara Komite dan orangtua/wali siswa dalam mengamalkan pembiasaan dari hasil pembelajaran selama di sekolah kepada siswa selama berada di luar sekolah.

5. Pengelolaan sekolah terkait pengembangan perilaku dan sikap belum terfokus dan terencanakan dengan optimal.
1. Memotivasi dan fasilitasi siswa agar memiliki perilaku dan sikap orang beriman melalui pembiasaan (budaya sekolah) dan keteladanan dalam menghayati dan mengamalkan sesuai dengan ajaran agama yang dianut.

2. Integrasi pengembangan sikap sopan santun siswa diSekolah dilakukan dalam bentuk kegiatan pembelajaran.

3. Contoh perilaku dan sikap orang beriman dan bertakwa meliputi:

Berdoa setiapmemulai dan mengakhiri kegiatan.

Santun dalam berbicara dan berperilaku.

Berpakaian sopan sesuai aturan sekolah.

Mengucapkan salam saat masuk kelas.

Melaksanakan kegiatan ibadah.

membudayakan mengucapkan terima kasih saat menerima bantuan atau diberikan sesuatu.

Menumbuhkan sikap saling menolong/berempati.

Menghormati perbedaan.

Antre saat bergantian memakai fasilitas sekolah.

LainNya.

\section{Rencana Pemenuhan Mutu}

Tahap ketiga yang dilakukan adalah penyusunan rencana pemenuhan mutu. Pada tahap ini. Tahap ini diawali dengan rapat antara kepala sekolah, tim pengembang, dan komite sekolah. Rapat tersebut menghasilkan keputusan sebagai berikut: (1) Pengumpulan Data Sopan Santun Siswa. (2) Membuat inovasi pengintegrasian sikap sopan santun siswa yang tehnik pelaksanaannya akan dimusyawarahkan bersama wali murid. Sebagai tindak lanjut dari hasil rapat tersebut, diadakan musyawarah bersama wali murid yang dilaksanakan satu hari setelah rapat tim pengembang. Dalam musyawarah tersebut tim pengembang menyampaikan program yang menjadi solusi terhadap permasalahan sekolah berdasarkan hasil analisis rapor mutu sekolah. Hasil musyawarah bersama wali murid diperoleh kesepakatan bahwa wali murid menyetujui dan mendukung program Implementasi PendidikanKarakter Sopan Santun Siswa Melalui Media Cantik (Contohkan Amati Laksanakan).

\section{Pelaksanaan Pemenuhan Mutu}


Tahap ini tim pengembang mutu sekolah mulai melaksanakan program sesuai perencanaan pemenuhan mutu pada tahap ketiga. Adapun tahapan pelaksanaannya meliputi: (a) Pengumpulan data; Proses pelaksanaan pengumpulan data ini dilakukan dengan observasi dan mendokumentasikan sikap santun siswa disetiap kelas dalam proses pembelajaran dan diluar kelas. Pengumpulan data dilaksanakan pada bulan September 2019 . Hasil pengumpulan data kemudian digunakan sebagai bahan acuan membuat skenario video pembelajaran sopan santun dengan media cantik dan bahan dalam pelaksanaan pemenuhan mutu. (b) Pelaksanaan kegiatan; Setelah bahan dan data yang terkumpul dirasa cukup maka tahapan yang dilakukan selanjutnya adalah membuat video pembelajaran sopan santun, dimana siswa selaku pemeran utama dalam video tersebut yang akan ditayangkan sebagai contoh yang akan mereka amati untuk dilaksanakan dalam kesehariannya.

\section{Monitoring dan Evaluasi}

Tahapan terakhir pada siklus pemenuhan mutu pendidikan di SD Negeri 11 Mataram tahun 2019/2020 adalah monitoring dan evaluasi. Siklus ini dilakukan oleh tim audit internal pada Tim Pengembang Mutu Pendidikan Sekolah (TPMPS).

Kegiatan monitoring dilakukan untuk mengetahui perkembangan proses pelaksanaan perbaikan. Kegiatan ini dilakukan sebanyak dua kali selama proses tahapan pelaksanaan perbaikan.

Tabel 4. Pelaksanaan Monitoring

\begin{tabular}{|c|c|l|}
\hline Hari/tanggal & Monitoring ke & \multicolumn{1}{|c|}{ Hasil monitoring } \\
\hline Sabtu,19 Oktober 2019 & 1 & Pekerjaan mencapai 50\% \\
\hline Sabtu,30 Nopember 2019 & 2 & $\begin{array}{l}\text { Pekerjaan mencapai 100\% dengan } \\
\text { hasil yang memuaskan }\end{array}$ \\
\cline { 2 - 3 } & $\begin{array}{l}\text { Penyelesaian kegiatan pembuatan } \\
\text { dan penayangan vidoe sopan santun } \\
\text { melalui media cantik sesuai yang } \\
\text { diharapkan. }\end{array}$ \\
\hline
\end{tabular}

Hasil evaluasi pelaksanaan kegiatan yaitu: (1) Seluruh siswa sangat antusias dan berusaha menampilkan yang terbaik saat pembuatan video (Media Cantik); (2) Siswa sangat menikmati video (contohkan) yang mereka perankan saat ditayangkan (amati) dalam pembelajaran dikelas dan memberikan imbas nyata setelah selesai pembelajaran.

\section{Kesimpulan}

Kesimpulan yang diperoleh dari penelitian ini antara lain adalah; (1) Karakter sopan santun di SD Negeri 11 Mataram belum terbina dengan dengan maksimal. Hal ini terlihat dari masih adanya indikator sopan santun yang masih kurang dilaksanakan oleh siswa. (2) Penggunaan Media Cantik (Contohkan Amati Laksanakan) untuk meningkatkan karakter sopan santun siswa di SD Negeri 11 Mataram terlihat hasilnya, akan tetapi tidak cukup dilakukan di sekolah saja, melainkan juga melibatkan orang tua siswa untuk saling bekerja sama dalam meningkatkan sikap sopan santun siswa.

\section{Saran}

Adapun saran yang dapat disampaikan berdasarkan hasil penelitian ini antara lain adalah; (1) Kerjasama seluruh guru untuk mengawasi dan membimbing peserta didik dalam menerapkan 
sopan santun terutama dilingkungan sekolah. (2) Pembiasaan sopan santun bukanlah kegiatan yang bisa dilakukan dalam waktu yang singkat, sehingga harus dilakukan secara berkesinambungan dengan melibatkan seluruh unsur sekolah baik guru, tenaga kependidikan maupun para siswa itu sendiri.

\section{Daftar Pustaka}

Akhwan, M. (2014). Pendidikan Karakter: Konsep dan Implementasinya dalam pembelajaran di sekolah/ madrasah. EL-TARBAWI. 61-67. https://journal.uii.ac.id/Tarbawi/article/view/3984

Darmiyati Zuchdi. (2013). Pendidikan Karakter; Konsep Dasar dan Implementasi di Perguruan Tinggi, Yogyakarta : UNY Press.

Dharma Kesuma. (2012). Pendidikan Karakter Kajian Teori dan Praktik di Sekolah. Bandung: PT. Remaja Rosda Karya.

Faqih, M., \& Mujiburrahman, M. (2018). MODEL KEPRIBADIAN BERKARAKTER DALAM QURAN DAN IMPLIKASINYA BAGI PENDIDIKAN KARAKTER $\begin{array}{llll}\text { ANAK DI SEKOLAH. Jurnal } & \text { Paedagogy, }\end{array}$ doi:https://doi.org/10.33394/jp.v5i1.2586

Ikrommullah, A. (2015). Tahapan Perkembangan Moral Santri Mahasiswa Menurut Lawrence Kohlberg. Jurnal Pendidikan Pancasila dan Kewarganegaraan, 77-87.

Irawan, M., \& Faqih, M. (2020). IMPLEMENTASI MANAJEMEN STRATEGIK PENDIDIKAN KARAKTER DI SMPN 2 MATARAM. Jurnal Paedagogy, 1(1), 8 16. doi:https://doi.org/10.33394/jp.v1i1.3054

Mulyani. (2016). Realisasi Pendidikan Karakter Melalui Kesantunan Berbahasa Guru Dalam Pembelajaran Di Kelas. Prosiding Seminar Nasional dan Call for Paper ke-2, 1-7.

Mustari, M. (2014). Nilai Karakter Refleksi untuk Pendidikan. Jakarta : PT RajaGrafindo Persada.

Moleong, Lexy J. (2017). Metode Penelitian Kualitatif, cetakan ke-36, Bandung : PT. Remaja Rosdakarya Offset.

Nitte, Y., \& Bulu, V. (2020). Pemetaan Implementasi Pendidikan Karakter di Sekolah Dasar se-Kota Kupang. Jurnal Kependidikan: Jurnal Hasil Penelitian dan Kajian Kepustakaan di Bidang Pendidikan, Pengajaran dan Pembelajaran, 6(1), 38-47. doi:https://doi.org/10.33394/jk.v6i1.2326

Nuraeni, N. (2020). PENDIDIKAN KARAKTER PADA ANAK USIA DINI. Jurnal Paedagogy, 3(2), 65-73. doi:https://doi.org/10.33394/jp.v3i2.3039

Noor, R. M. (2012). Mengembangkan Karakter Anak Secara Efektif di Sekolah dan Dirumah. Yogyakarta: Pedagogia.

Ramdhani, M.A. 2014. Lingkungan Pendidikan dalam Implementasi Pendidikan Karakter. Jurnal Pendidikan Universitas Garut. $8 \quad$ (1), 28 - 37. http://digilib.uinsgd.ac.id/5122/1/201403\%20Lingkungan\%20Pendidikan\%20dalam \%20Implementasi\%20Pendidikan\%20Karakter.pdf

Ratnasari, D., \& Arsana, I. M. (2013). Penanaman Sikap Sopan Santun Sebagai Pendidikan Moral Kepada Siswa Melalui Tata Tertib Sekolah di SMK PGRI 2 Kertosono. Kajian Moral dan Kewarganegaraan. UNESA, Vol. 2, No. 1.

Sari Wijayanti, T. (2018). Penerapan Terapi Cobra untuk Merubah Karakter Siswa SMAN 7 Mataram. Jurnal Kependidikan: Jurnal Hasil Penelitian dan Kajian Kepustakaan di

Bidang Pendidikan, Pengajaran dan Pembelajaran, 4(2), 206-214. doi:https://doi.org/10.33394/jk.v4i2.1132 